\title{
„VÁLTOZNAK AZ IDŐK”: A NŐK HELYZETE GHÁNÁBAN
}

Szerző:

Mező Lilla Dóra

Eötvös Loránd Tudomáynegyetem

Szerző e-mail címe:

dori.mezo1@gmail.com

\section{Lektorok:}

Harai Dénes (PhD, CSc)

Nemzeti Közszolgálati Egyetem

Kenyeres Attila Zoltán (PhD)

Debreceni Egyetem

...és további két anonim lektor

\begin{abstract}
Absztrakt
„Változnak az idők” - nyilatkozta Mary Ama Kudom-Agyemang nemzetközi díjakkal rendelkező ghánai újságírónő. A most Ghánába utazók megfigyelhetik, hogy (miközben még erősen érezhetők az afrikai tradiciók a nők mindennapjaiban) a média, az oktatás és a modernizáció hatására egy új életfelfogás kezd kialakulni a fiatalok körében. A következőkben ezt a változást fogjuk bemutatni helyi férfi és női lakosokkal 2020. februárjában készített interjúk öszszesített tapasztalatain keresztül.
\end{abstract}

Kulcsszavak: Ghánai Köztársaság, nők emancipációja

Diszciplina: médiatudomány, társadalmi nem tudománya

\begin{abstract}
'TIMES ARE CHANGING': THE SITUATION OF WOMEN IN GHANA

'Times are changing' said the Ghanaian journalist Mary Ama Kudom-Agyemang with international awards. Those who travel to Ghana may observe that, while African traditions are still strongly felt in women's daily lives, media, education, and modernization are starting to create a new outlook on life for young people. In the following, we will present this change through the combined experience of interviews with local male and female residents at February of 2020.
\end{abstract}

Keywords: Republic of Ghana, female emancipation

Disciplines: Media, Gender Studies

Mező Lilla Dóra (2020): „Változnak az idők”: a nők helyzete Ghánában. Lélektan és hadviselés interdiszciplináris folyóirat, II. évf. 2020/1. szám. 95-107. doi: 10.35404/LH.2020.1.95 


\section{Országismertető}

Ghána (hivatalosan Ghánai Köztársaság, államforma: elnöki köztársaság) Nyugat-Afrikai ország, néhány fokkal északra az Egyenlítőtől (1. ábra). Az Egyesült Királyságtól való függetlenség kikiálltása 1957. március 6-án történt meg - Ghána volt az első afrikai ország, amely a gyarmati országok közül szabad lett. Fővárosa: Accra.
Ghána éghajlata trópusi, s két évszak van: a száraz és az esős (a látogatásokat a novembertől márciusig tartó száraz évszakra érdemes tervezni - Briggs és Rushton, 2019). Az országot állandóan magas hőmérséklet és nagy páratartalom jellemzi. Délen, a partvidéken az évi csapadékmennyiség 2000 mm felett van, északon csak 1000 mm (nem meglepő módon a déli rész a lakottabb).

\section{1. ábra: Ghána földrajzi elhelyezkedése és régioii (Net1, Net2 alapján)}

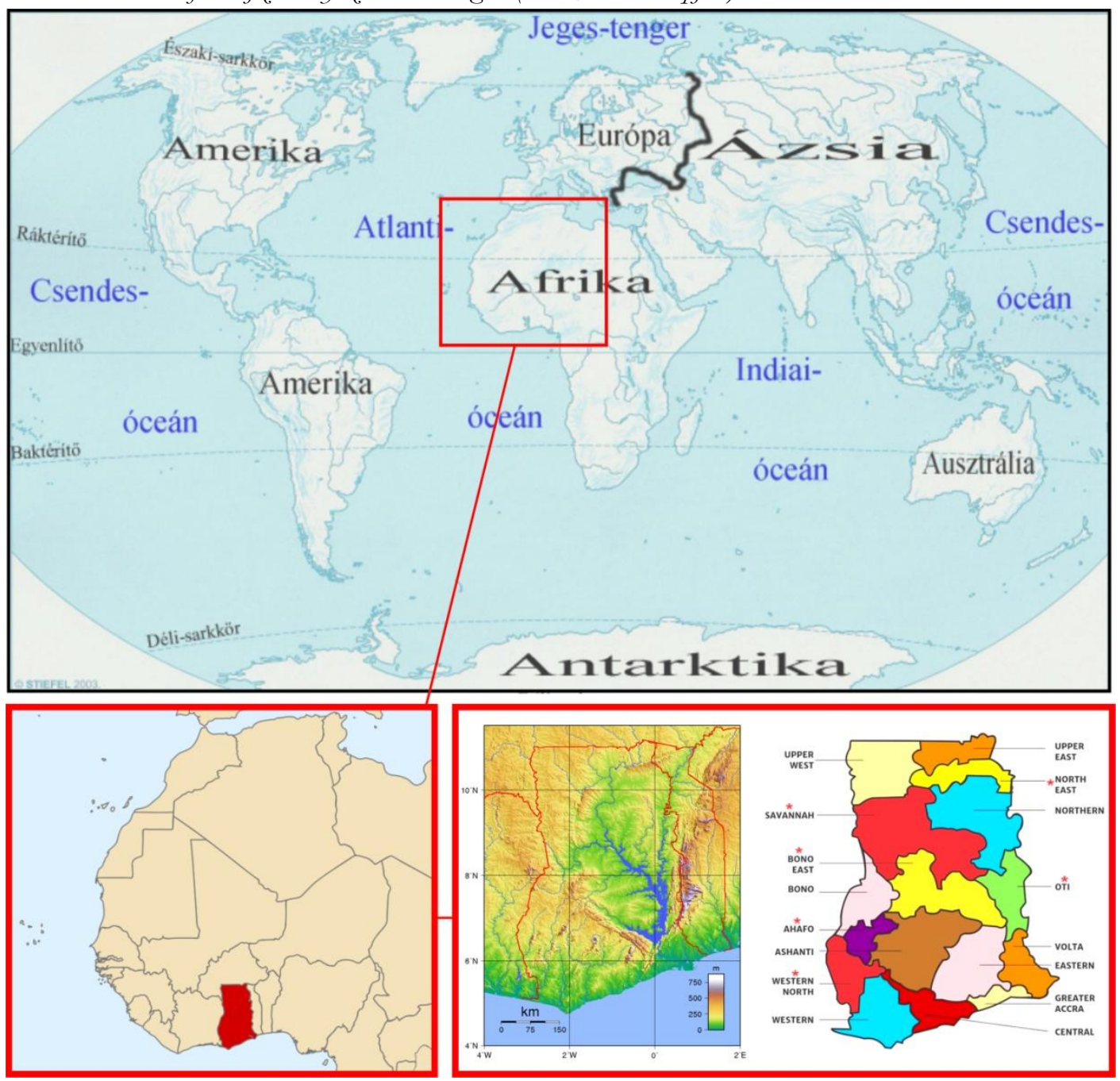


Az ország területe $238540 \mathrm{~km}^{2}$. Az ország területének mintegy 3,6\%-át teszi ki a 8500 $\mathrm{km}^{2}$ területű Volta-tó (a világ legnagyobb mesterséges tava).

Népesség és lakosság. A népesség 27 millió fö körüli, a népsűrūsége pedig 101 fő $/ \mathrm{km}^{2}$ (öszszehasonlításképpen a mintegy 10 millió fős népességű Magyarország népsűrűsége kb. 106 fő $\left./ \mathrm{km}^{2}\right)$.

A lakosság jellegzetessége, hogy sokféle etnikumból tevődik össze - zömében sötét bőrű szudáni népcsoportbeliek. Relatív gyakoriság szerinti sorrendben az alábbi etnikumok jellemzők:

- Akan: 44\%,

- Moszi: $16 \%$,

- Kisebb szudáni törzsek és európai származású lakosok: 15,4\%,

- Ewe: $13 \%$,

- Gadaigme törzsek: 8\%,

- Gurma: 3\%,

- Joruba: 0,6\%.

Az ország régen brit gyarmat volt, ezért a hivatalos nyelv az angol. Ghánában azonban 49 helyi nyelv is létezik (1. melléklet)! Ebből 37-nek van írott formája is. Általánosan elmondható, hogy az egész országban beszélnek angolul és a saját helyi nyelvükön kívül mindenki beszéli a legelterjedtebb ghánai nyelvet: a Twi (másnéven: Akan) nyelvet. Napjainkban a francia nyelvoktatás is egyre elterjedtebb, mivel a többség belátja, hogy az angolon kívül szükségük van egy második világnyelvre, hogy jobb munkalehetôségeket kaphassanak.

Vallás. Ghána lakói igen vallásosak: 68\%uk keresztény (közülük 24,1\% pünkösdi/kariz-matikus, 18,6\% protestáns és 15,1\% katolikus, a többiek egyéb keresztény feleke- zethez tartoznak), 15,9\%-uk muzulmán, 8,5\%-uk törzsi vallású, $0,7 \%$-uk egyéb vallású (a lakosság kb. 7\%-a vallásáról nincs információ). Nőket is érintő vallási aspektusa van annak, hogy Ghána azon országok egyike, amelyekben egyaránt jelen van a monogámia és a poligámia is.

Az ország nőket érintő babonás sajátossága továbbá, hogy boszorkányfalvakba üldözik azokat a kiközösített nőket, akiket valamilyen oknál fogva a boszorkánysággal gyanúsítanak.

Gazdaság. Az országra jellemző GDP: 54 330 millió USD körüli, aminek 50\%-át a fakitermelés és a bányászat, 40\%-át a mezőgazdaság, 10\%-át a feldolgozóipar adja.

Legfőbb exporttermék az arany és a kakaó, de ezek mellett jelentős a fa (Az országban 55 $170 \mathrm{~km}^{2}$ őserdő volt 2005-ben, ami 1154 $\mathrm{km}^{2}$-rel csökken évente!), a bauxit, az aluminíium, a mangánérc, a gyémánt és a kőolaj export is. A jellemző importtermékek közt első helyen említendő az élelmiszer (Ghána ebből szempontból nem tekinthető önellátónak), a közszükségleti cikkek, valamint az ipari termékek.

A Ghánára jellemző agrárgazdaság (Huq és Tribe, 2018) húzótermékei a farmokon termesztett kakaón és pálmaolajon (Brewer és tsai, 2014) kívül, a halászközösségek által kitermelt haláru. Egyik leghíresebb halpiac az elminai.

Ghána főbb kereskedelmi partnerei között találhatjuk a következő országokat: Egyesült Királyság, Németország, Nigéria, USA, Olaszország, Franciaország, Spanyolország, Togo.

A nemek közötti foglalkoztatási különbségekről az alábbiakban lesz még szó. 
Média. A ghánai sajtószabadság talán a legnagyobb Afrikában (Net3): sok és sokféle média-termékkel találkozhatnak a polgárok, ami többek között a nőkkel kapcsolatos közvélemény formálásában, a kultúra alakításában mindenképpen jelentős tényező.

Szubjektiv tapasztalatok. A Szerző országlátogatása során szerzett benyomások: a közbiztonságot jónak tapasztaltuk. Bár a városokban a közutak karbantartottak, de a városokon kívül szinte mind rossz minőségú. Ételeiket rendszeresen csípősen készítik el, még cukorkával és ananászlével is találkozhatunk csípős formában.

Történetelmi, kulturális és idegenforgalmi szempontból is igen meghatározó az Elmina kastély, ahol a rabszolgasorsba kényszerített, eladásra szánt embereket tartották fogva, mielőtt átlépték a „Door of No Retrun”-t, a „Nincs Visszaút Kapuját” (Van Dantzig, 1999; Net4; lásd: 2. ábra).

Egyéb fontosabb látványosságok közé tartoznak a hagyományos temetések (amiket nagy ünneplés jellemez), a zsúfolt helyi piacok, a tengerpartok (amelyeken lovakkal és meglepő mutatványosokkal találkozhatunk), valamint a Kakum Nemzeti Park, ahol például 7 óriás fát összekötő 350 méter hosszú függóhíd-rendszeren sétálhatunk az esőerdő lombkoronájában - 3. ábra).

Kulturális szokás, hogy bal kézzel nem illik gesztikulálni, kezet fogni, átvenni dolgokat vagy enni, mert illetlenségnek számít (Salm és Falola, 2002). Magyarországról utazók számára Ghána egyrészt vízum-köteles ország, másrészt mindnekinek rendelkeznie kell kötelezô (sárgaláz elleni), valamint ajánlott (például: hepatitisz A és B, meningitisz stb.) védőoltásokkal.

\section{2. ábra: Door of No Return (forrás: a Szerző)}

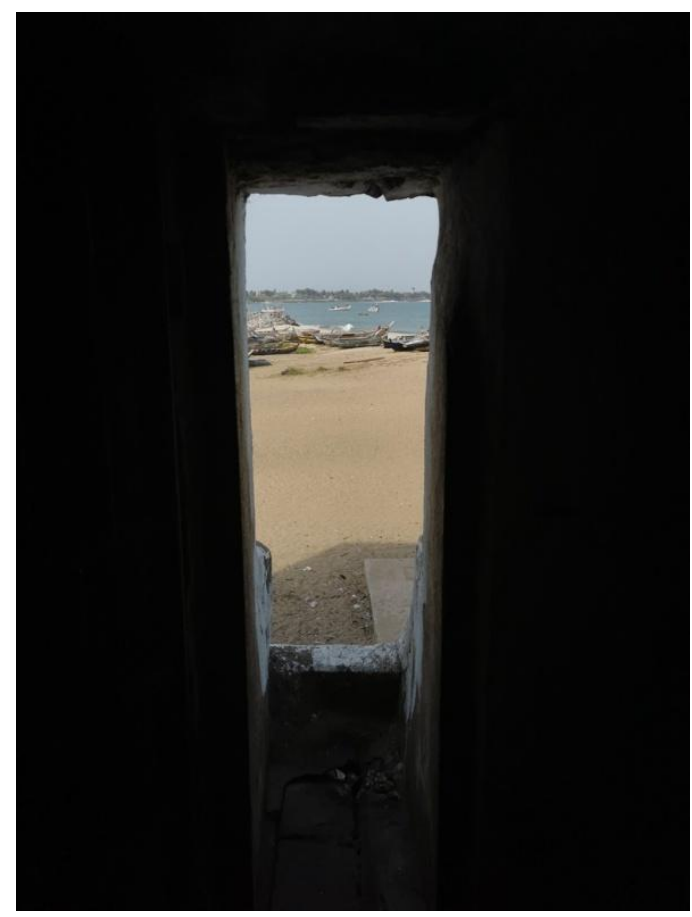

3. ábra: „Canopy Walkway”: 350 méter hosszú függóbid-rendszer a ghánai Kakum Nemzeti Parkban (forrás: a Szerzó)

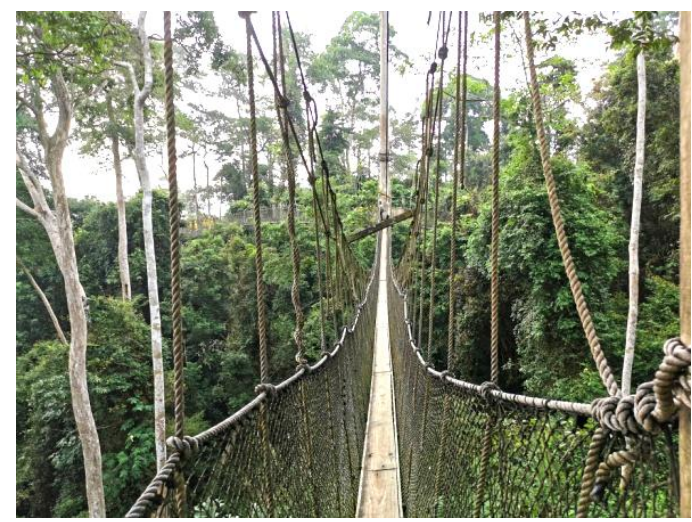


A tanulmány további részében a ghánai nők helyzetét a házasság, a családtervezés és gyermekvállalás, a nők elleni erőszak, az oktatás és a munkavállalás szempontjából tekintjük át.

\section{Házasság}

A házasság és a szerelem terén a ghánai nők helyzetében jelentős változás következett be az elmúlt néhány évtizedben. E változás megnyilvánul a megszervezett, illetve szerelmi házasságok terén, valamint a korai házasságok, és az egyedülálló és elvált nők megítélése kapcsán is.

Korábban az Akanok (a népesség 44\%-át adó etnikum) által lakott régiókban gyakori volt a család által megszervezett eljegyzés, aminek a célja: gazdag férfihoz adni a lányt. Attól kezdve, hogy eljegyezték, a lányról a férfinak kellett gondoskodni. Sok esetben rosszul bántak a nővel. Például három évtizede még előfordulhatott, hogy egy középiskolai tanár, majdnem megölte a jegyesét, és ez ellen a közösség nem tehetett semmit. De ez már a múlt, manapság a család által megszervezett eljegyzés háttérbe szorult.

Napjainkban a családnak a párválasztásról ugyan meg lehet a véleménye, de már a családi támogatásból nem esnek ki azok a nők, akik maguk választják a férjüket. Különösen a fiatal nők esetében jellemző, hogy a családjuk azt szeretné, hogy a lány egy híres vagy gazdag embert találjon. Ha ez nem sikerül, akkor a család kezdetben nem biztos, hogy örül, de nem állnak a fiatalok útjába.

Mindeme változásoknak azonban sajátos következménye az lett, hogy a tradicíonálishoz képest nagyobb fokú szexuális szabad- ság miatt elterjedtebbé vált a korai teherbeesés. A tinédzserkorú anyák azonban még nem tudják, hogyan kezeljék a csecsemőket (4. ábra).

4. ábra: terhességre felkészitō képzést, illetve óvszerhasználatot propagáló utcai plakátok (forrás: a Szerzó)
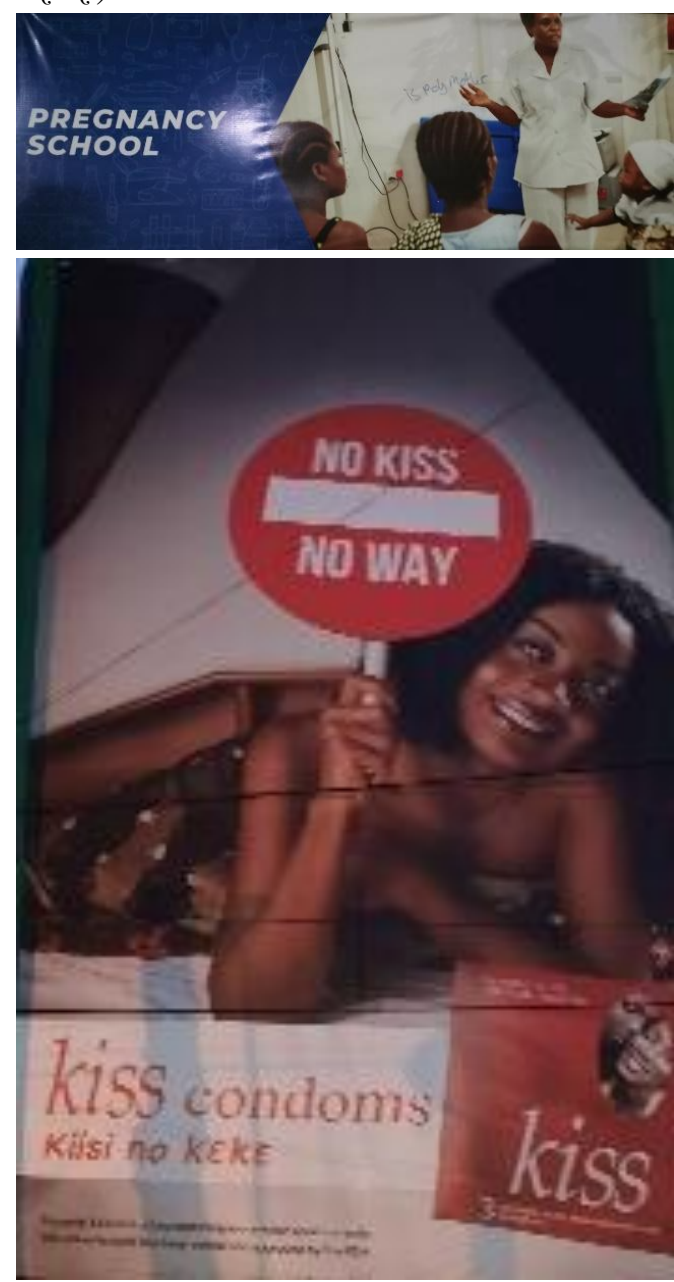

Két-három évtizeddel ezelőtt még jellemző volt, hogy amikor a lányoknál első alkalommal jelentkezett a menstruáció, akkor néhány 
hétre elkülönítették és felkészítették őket a férfiakkal való bánásmódra, kvázi szexuális felvilágosításban is részesültek. E szertartássorozat jelezte, hogy a gyermeklányból felnőttnek tekintett nővé vált. Minden pozitívuma ellenére szomorú tény, hogy egyes közösségek esetében ennek a pubertás rítusnak a női nemiszerv csonkítása is része volt (és nagyon ritka esetekben ugyan, de még napjainkban is az).

\section{Nők elleni erőszak}

Noha napjainkban a női nemi szervek (pubertás rítus keretein belül történő) megcsonkítása már csak ritka esetekben fordul elő, a ghánai nőknek máig sokféle erőszakkal kell szembenézniük. A nők kiszolgáltatottságának egyik speciális meg-nyilvánulása például a boszorkánytáborokba toloncolás gyakorlata, és sajnos a nők megerőszakolása is súlyos probléma. A leggyakoribb bántalmazási forma a családon belüli erőszak. Interjúalanyaink elmondása alapján ez szinte minden háztartásban előfordul.

Magának a házasságkötésnek is van kialakult, sok törzs által követett hagyománya. A közösségekben legelsimertebb házasságkötési forma szerint a vőlegény a mennyasszony szülei számára összeállít egy listát, ami tartalmazza, hogy a mennyasszonynak és családjának mit kell adnia a vőlegény és családja számára. Ez a lista a mennyasszony árát akár pénz vagy italok formájában is tartalmazhat- ja... Ezenkívül a mennyasszonynak rendelkeznie kell egy utazótáskával, ami tele van különböző ruhákkal, alsó nemúkkel, cipőkkel, ékszerekkel (beleértve a jegygyürüket is), Bibliával és egyéb dolgokkal. A vőlegénynek szintén kell fizetnie egy bizonyos (változó) összeget a mennyasszony apjának, anyjának és testvéreinek.

A felsorolt dolgokat a vőlegénynek és a mennyasszonynak egy ünnepség keretében kell bemutatnia, mely szertartáson mindkét családnak jelen kell lennie és tanúskodnia kell. A darabok bemutatása és átadása alatt a mennyasszonynak végig egy külön szobában kell várakoznia. Miután ennek vége, előhozzák a mennyasszonyt, hogy találkozzon a vőlegényével. Ettől fogva a két fél a rítus szerint házaspárnak minősül. Ezután a férfi és a nő családjának két-két képviselője tanácsokat ad a párnak.

Attól függően, hogy a párnak mekkora vagyona van, és hogy mennyit készültek, a ceremónia minden résztvevőjét megajándékozzák. Végül a házasságot nagy ünnepléssel pecsételik meg. Ez a fajta házasságkötés sok ghánai nő vágya, s a közösségekben a legnagyobb megbecsülésnek a házassági rítust követően született gyermekek örvendenek.

Érdekesség: néhány törzsi területen a férfinak a temetés előtt akkor is el kell végeznie a szertartást (a holttesttel való házasságkötést), ha a mennyasszony időközben meghal. 
A korai házasság (különössen a muszlim közösségekben) még az 1980-as években is gyakori volt. Mint egy napjainkban negyvenes éveiben járó hölgy (aki tizenöt évesen házasodott szerelemből) megjegyezte: „Úgy vélem, hogy akkoriban elég tisztességtelen kor volt. Manapság, az oktatásnak köszönhetően, jellemzőbbé vált, hogy a nők a huszas éveikben kötnek házasságot”. Ő a lányát már arra neveli, hogy először a tanulmányaira koncentráljon: „Azt hiszem, ebben a korszakban minden fiatal nőnek feltétlenül szüksége van arra, hogy először a karrierjére összpontosítson. A szerelem, majd jön vele együtt, amikor jönnie kell’. Ezt a modern felfogást több fiatal nő is vallja. Az egyik 21 éves piaci árus például az egyetemen tanul, nincs párja, de ô már egyáltalán nem érez kulturális nyomást a házasság és a gyerekvállalás terén. Ô az igaz szerelmben hisz.

Megjegyzendő, hogy Ghánában az egyedülálló nô státusza még napjainkban is kulturális megbélyegződéssel jár az idősebb korosztály részéről, különösen a vidéki közösségekben. A ,szingli életért” lenézhetik az embert és sokan azt gondolják, hogy a lány rossz természete miatt nincs férje. A válás esetében ez a „lenézés” moderáltabb. Sokkal kiegyensúlyozottabb, mert az emberek belátják, hogy ez nem csak a nő hibája. Tradicionálisan és családilag viszont nem bátorítják erre a nőket. Sokan a gyerekek miatt nem is válnak.

\section{Családtervezés, gyermekvállalás}

Ghánában egyaránt jelen van a patri-, illetve a matrilineáris öröklődési rendszer. Például a Greater Accra régióban (v.ö.: 1. ábra) patrilineáris (apaági) öröklési rendszer szerint élnek. Mivel házasság után a nők a férj családjához tartoznak, attól a családtól, amelyikbe beleszülettek nem is kapnak örökséget. Az itt élő nôk és szüleik számára ezért különösen fontos a házasság intézménye. A családokban a fiúk kiemelt szerepet kapnak az öröklés miatt is. Ez azonban a feleségekre nagy terhet hárít, hiszen ha nem szülnek fiúgyermeket, akkor a férj szempontjából „értéktelenné” válhatnak. Néhány szélsőséges esetben a férj még el is hagyja a feleségét, ha nem tud neki fiút szülni. Egy Ghána északi régiójában élő közösség vezetőjének szavait idézve: „Nézd, ez a mi rendszerünk. Ez a kultúránk. Az emberek így örökölnek."

Ezzel szemben az akanok által lakott régiókban matrilineáris (anyaági) öröklés van. Ezekben a családokban az, hogy valaki házas vagy sem, nem érdekes mindaddig, amíg egy nőnek van gyermeke. Az nem fontos, hogy ki az apa. A férfiak emiatt a matrilineáris rendszerben gyakran nem is foglalkoznak a saját gyerekeikkel, mivel azokat az anya családjához tartozónak tekintik. Ugyanakkor testvérük gyermekeire figyelmet fordítanak, hiszen őket inkább tartják a saját családjuk tagjának.

A gyermekvállalás nagy prioritású dolog Ghánában. Ha egy nőnek nincs gyermeke, akkor „gyerektelen nő”, „reménytelen nő” és hasonló bántó címkékkel bélyegezhetik meg. Ghána északi területein még ,boszorkány”nak is nyílváníthatják a gyermektelen nőt, és akár úgynevezett „boszorkány faluba” is száműzhetik. Éppen, ezért vált jellemzővé az utóbbi időkben, hogy sokan a házasság előtt a nemzőképességre vonatkozó tesztet végeztetnek el.

A nemek közötti diszkrimináció egyik megnyilvánulását mutatja egyik interjúala- 
nyunk megjegyzése, miszerint a közvéleményben meggyökeresedett, hogy: „Egy férfi nem lehet nemzőképtelen. A gyermektelenség csak a nő hibája lehet". A nemzóképességre vonatkozó tesztek ezt a hiedelmet alaposan kikezdik, így voltaképpen a nôk védelmét és a közvélemény ezirányú formálását is szolgálják. Mindemellett, ha egy nőnek csak egy gyereke van, akkor is lenézik azért, hogy miért nincs neki több. Nem az a fontos tehát, hogy a gyerekek jólétben éljenek, hanem az, hogy a nő bizonyítsa, hogy több gyereket is világra tud hozni.

\section{A csábitás deréklánca}

A ghánai nők sajátos szexuális praktikákkal is élhetnek a férfiak elcsábítása érdekében (ami nem érdektelen a családtevezés szempontjából sem).

A fôváros piacán árusító fiatal nők elmondása alapján Ghánában a férfiaknak való imponálás gyanánt szokás egy (akár egyszerű műanyagelemekből álló, akár értékesebb összetevőkből készült) gyöngysorból készült láncot kötni a nők derekára.

Ezt a derékláncot semmikép sem illő nadrágon kívül hordani, azonban, ha egy nő tetszeni akar egy ghánai férfinak, akkor a lánc egy kis része kilátszódhat a ruha alól.

$\mathrm{Az}$ eladólányok elmodása alapján ez olyannyira felkelti a férfiak érdeklődését, hogy közösülés során minden ruhadarab eltűnhet a nőről, de az öv nem! Állítólag ennek az az oka, hogy a ghánai férfiaknak tetszik a hang, amit aktus közben a lánc kiad. Az egyik árus szerint megesik, hogy ilyenkor közösülés közben a férfiak elüvöltik magukat: „Szeretem az övedet!”.

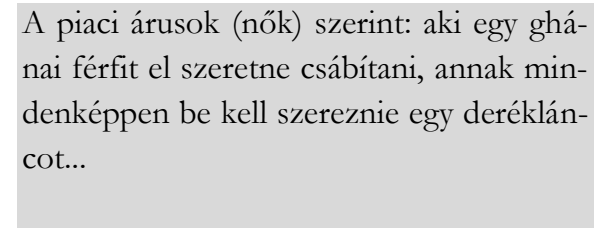

A nukleáris család ,intézménye” jóformán nem létezik Ghánában. A ghánai kultúra szerves része a nagy család, ami érzelmi és anyagi támogatást is jelent a családtagok számára.

Beállítódásukat jól szemlélteti két interjúalany ezzel kapcsolatos megjegyzése. „Ha a nagybátyádnak van elég pénze, segít a napi betevőben, iskoláztatásban, kereskedelemben, bármiben, hogy tudj magadról gondoskodni” - mesélte egy ghánai férfi. „Ha a nagy fiútestvér nem segít, akkor gyenge” - egészítette ki egy hölgy. Ennek megvannak az előnyei. Az anyagi támogatáson kívül, a családtagok mindig számíthatnak arra, hogy van körülöttük valaki, aki figyel rájuk. Általában mindannyian egy nagy családi házban élnek. Azonban, ha egy nő megházasodik, akkor a férjéhez költözik - ugyanakkor a családi eseményekre még utána is hazajár a szülői házba.

A nagy család hátránya ellenben, hogy az emberek egy része kihasználja ezt a rendszert és teljesen ráhagyatkoznak a családjukra. Például: az egyik interjúalany unokatestvérének három gyermeke van, de sem ő, sem a férje nem dolgozik. Ehelyett jóformán a nagymamán élősködnek. Mivel a nagymama már elég idős, félő, hogy hamarosan meghal és akkor a többi családtagnak kell gondoskodni a három gyermekrôl és szüleikről - amennyiben hajlandóak rá. 


\section{Oktatás}

Ghánában minden polgárnak joga van az ingyenes közoktatáshoz (5. ábra), ami azonban a családokat terhelő járulékos költségekkel jár, és a gyermekek ellen irányuló családon belüli erőszak (fizikai elhanyagolás, verbális és fizikai bántalmazás) miatt nem minden kiskorú számára elérhető.

\section{5. ábra: Iskola Nyameagyiso-ban (forrás: a Szerzó)}

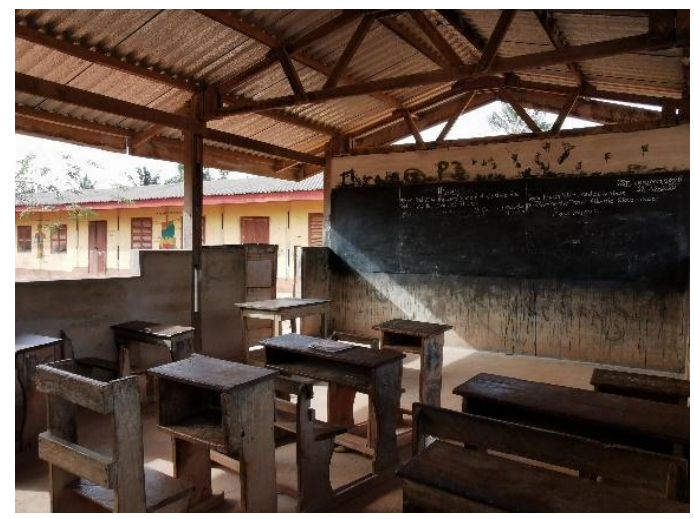

A gyerekek iskoláztatása ugyan formálisan nem az anyára hárított feladat, de a legtöbb esetben a nők látják be, hogy milyen sokat jelent gyermekük (és saját) jövőjére nézve, ha azok tanult emberré válnak. A nőkre jellemző tehát, hogy áldozatokat vállalnak azért, hogy gyermekeik oktatásban részesüljenek. Ennek érdekében személyes tárgyaikat is készek eladni (ezt az áldozatot akkor érthetjük meg igazán, ha figyelembe vesszük gyakran ingatag anyagi helyzetüket).

Mint fentebb említettük, ingyenes ugyan a közoktatás, ám a családokra még így is jelentôs anyagi terhek hárulnak. Az oktatáshoz kapcsolódó költségként jelentkezik ugyanis a tanulók egyenruhájának, illetve a tanköny- veknek az ára. Ezek biztosítása nem minden esetben megoldott.

Bizonyos esetekben a gyerekek a családon belüli erôszak áldozataiként maradnak ki az iskolából. Ennek az oka, hogy a gyerek közül sokan nem a szüleikkel nőnek fel. Mint egy hölgy elmesélte, az apja a nagyszülők tíz gyereke közül az első szülött volt, ezért keményen dolgozott, hogy segítsen a családjának. Hála neki a testvére iskolába tudott járni, aki ezt úgy hálálta meg, hogy később a történetet mesélő hölgyet és egy unokatestvérét magához vette. A felesége viszont ennek nem örült, és szóban bántalmazta a gyerekeket: szidta az anyjukat, az apjukat, őket. Nem adott nekik mindig enni (egy időben a szomszéd segítette ki ez ügyben a gyerekeket). Minden házimunkát a gyerekek csináltak, mert a feleség nem csinált meg semmit. A nő arra is rá akarta venni a férjét, hogy ne hagyja a gyerekeket továbbtanulni menni. Az interjúalanyunk ekkor a sarkára állt és nem hagyta, hogy megakadályozzák az iskoláztatását. Erről az időszakról a következőt nyilatkozta: „Folyamatosan azt mondom az embereknek, hogy ha elég szerencsés vagy és felnőhetsz a szüleiddel, nagyon hálásnak kell lenned, mivel némelyikünknek nincs választása. Biztos vagyok benne, ha a szüleimmel nőttem volna fel, nagyon más lenne minden. De végül hálás vagyok, mert keményebbé váltam. Ezért bárhol élhetek, bárhova mehetek."

Végül meg kell jegyezzük, hogy az utóbbi időkben a nyelvoktatás szerepe megnőtt. Az 1. melléklet tartalmazza a jellemző helyi nyelveket, amelyekből legalább egyet beszélnek a hivatalos angol nyelv mellett. Manapság más világnyelvek tanulása iránt is egyre nagyobb az érdeklődés. 


\section{Munkavállalás}

Alapjában véve a férfi a családfentartó, de ez is egyre kiegyensúlyozottabbá válik a nemek között. A nők különösen a falusi közösségekben dolgoznak nagyon keményen, mert „A férfiak egy része lusta és felelőtlen” summázta a helyzetet egy ghánai asszony. Ugyanakkor a városi környezetben is egyre jellemzőbb, hogy a családi bevétel jelentős részét vagy egészét a nők keresik meg. A fővárosban ebből a szempontból már egészen elmosódnak a nemek közti különbségek.

Ghána gazdaságában jelentős szerepet játszik a kakaótermesztés és a halászat. Nagy különbségeket találhatunk a férfiak és nők munkavállalási lehetőségei között e két húzóágazatban.

Sokan farmokon, mezőgazdasággal foglalkoznak (6. ábra). Ez nyilvánvaló előnnyel jár számukra: „Ha farmon dolgozol az azzal jár, hogy biztos nem leszel éhes” - világított rá egy helyi nő. Egy kakaó farmon például, a nôk a termelésben és a feldolgozásban is résztvesznek. Igaz ugyan, hogy a többségük jobban szeret a feldolgozásba (a pálmaolaj előállításába, a kakaóbabok kiszárításába) bekapcsolódni. Néhányuk azonban büszke arra, hogy ők a termelésben is részt vesznek.

A halászközösségekben azonban még mindig nagy a különbség a férfiak és nők között (7. ábra). Egy elminai lakost kérdeztünk a halászmesterségről a helyszínen. Mint elmondta, a halászközösségekben kizárólag a férfiak szállhatnak hajóra és vehetnek részt a halászatban. Ami érdekes, mert a nők rengeteg hivatásban jelen vannak a mai társadalmukban, de a halászatból ki vannak rekesztve. Ellentétben a piaci kereskedelemmel, amiből
6. ábra: Nök a kakaótermesztésben és pálmaolaj

készités közben (forrás: a Szuerzö)

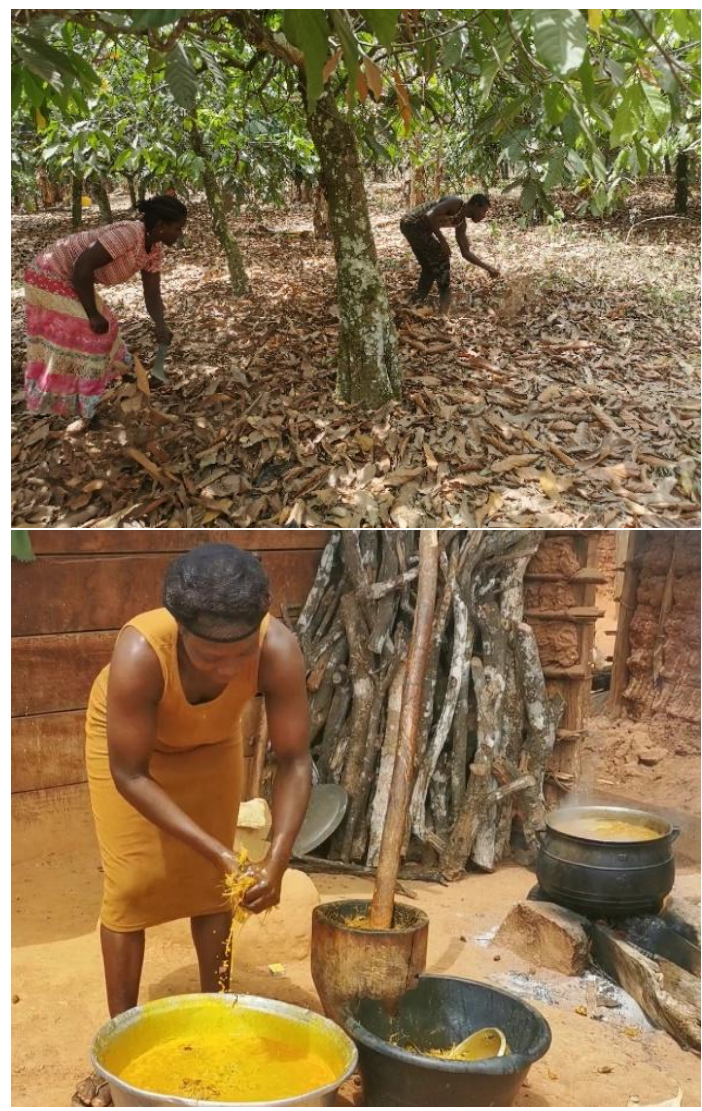

7. ábra: Elminai halászok (forrás: a Szerzó)

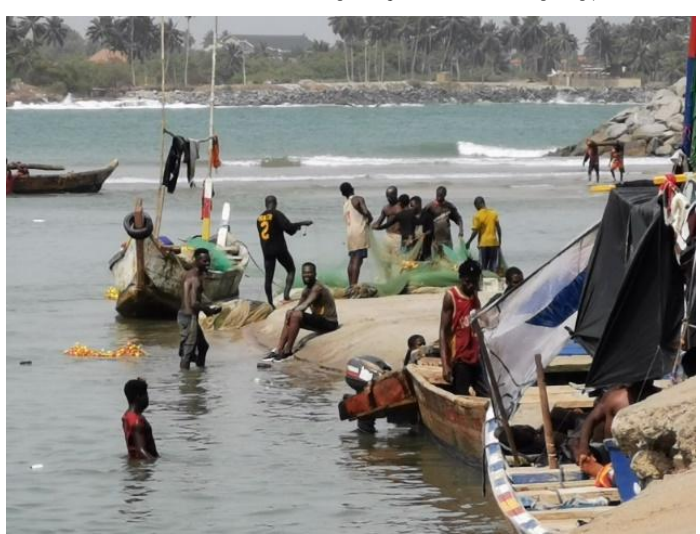


ezekben a közöségekben a férfiak rekesztődnek ki.

A halak eladása teljes mértékben a nők feladata. A jövedelem elosztása százalékos alapon történik, ahol nagy különbségek vannak a férfiak és a nők között. Általában a nők eladják a halat és a bevétel 20\%-át megtartják. A maradékot pedig a férfi kapja.

Általánoságban véve a ghánai nők legnagyobb elismerése a piacon, kereskedelmi helyzetekben van. Kivéve a helyi muszlim közösségeket, ahol gyakori, hogy a nőnek az egyetlen feladata, hogy otthon legyen.

Egy érdekes szokás figyelhető meg a lakosság és az utcai árusok között, ha Ghánában járunk. Tradicionálisan mindent a fejükön hordoznak (8. ábra). Legyen az banánfürt, ital, háztartási szer stb. Később ez idővel akár a gerincükre is káros lehet - főként a nőknek, akik nehéz fa dolgokat is cipelhetnek a fejükön. Sokszor a fejen levő árukon kívül még egy kisgyereket is hordoznak a hátukon. Férfiak is szoktak így árusítani, de ez a fajta munka inkább a nőkre jellemző. Általában mindenféle kötél vagy kézzel rásegítés nélkül, tökéletes egyensúlyal hordozzák a portékáikat a fejükön.

Fentebb már szó esett az oktatás helyzetérôl. Munkavállalói (pedagógusokat érintô) oldalról a tanári fizetésekkel Ghánában is probléma van ugyan, ám a helyzet sokat javult az utóbbi években, de a visszajelzések alapján máig nem keresnek eleget.

A média viszonylag jól fizető elhelyezkedési lehetőséget jelent. Ghána a sajtószabadságáról híres, ahol jellemzően nagyon objektív cikkek készülnek. A 2019-es World Press Freedom Index szerint 180 vizsgált ország- ból, a sajtószabadság szempontjából, Ghána a 27. legszabadabb ország (Forrás: Net3). Az újságíróknak az a lehetőség is megadatik, hogy sokat utazzanak a világban, más kontinensekre is ellátogathassanak (például továbbképzés vagy konferencia keretében).

A migráció nagy hatással van Ghána gazdaságára. Sokan az országba szaktudással érkeznek vagy elvállalnak olyan munkákat is, amit a helyiek nem, pedig szükség van rá. Nyugat-Afrikából (főként a muszlim poligám családok), azért mennek Európába dolgozni, mert nincs elég pénzük, ételük a család számára. Ilyenkor a család összegyújti a pénzt és kiküldi a férjet, hogy próbáljon szerencsét. Azok, akik Európában találnak munkát, rendszeresen pénzt küldenek haza a családjuknak és mikor visszajönnek, a kint megszerzett tudásukat tudják kamatoztatni.

Hátrány az ország számára, hogy a legtöbb orvos külföldön vállal munkát, ha lehetősége van rá. Ugyanakkor ezt kompenzálja, hogy környező afrikai országokból kiinduló immigráció miatt van utánpótlás. Ghána az egyik legstabilabb ország a régióban - ezért vonzó célország a környező országokból érkező bevándorlók számára.

\section{Zárógondolatok}

A szerző szubjektív tapasztalata, hogy a ghánai lakosok nagyon barátságosak és meglepően nyíltan és szívesen osztják meg történeteiket. Az ország a változások olyan korszakát éli meg napjainkban, hogy egyszerre nyerhetünk bepillantást annak múltjába, jelenébe és jövőjébe. Összegezve mind a munka- 
8. ábra: fejtetön hordozott termékeek (forrás: a Szerzó saját fotóiból készitett montázs)

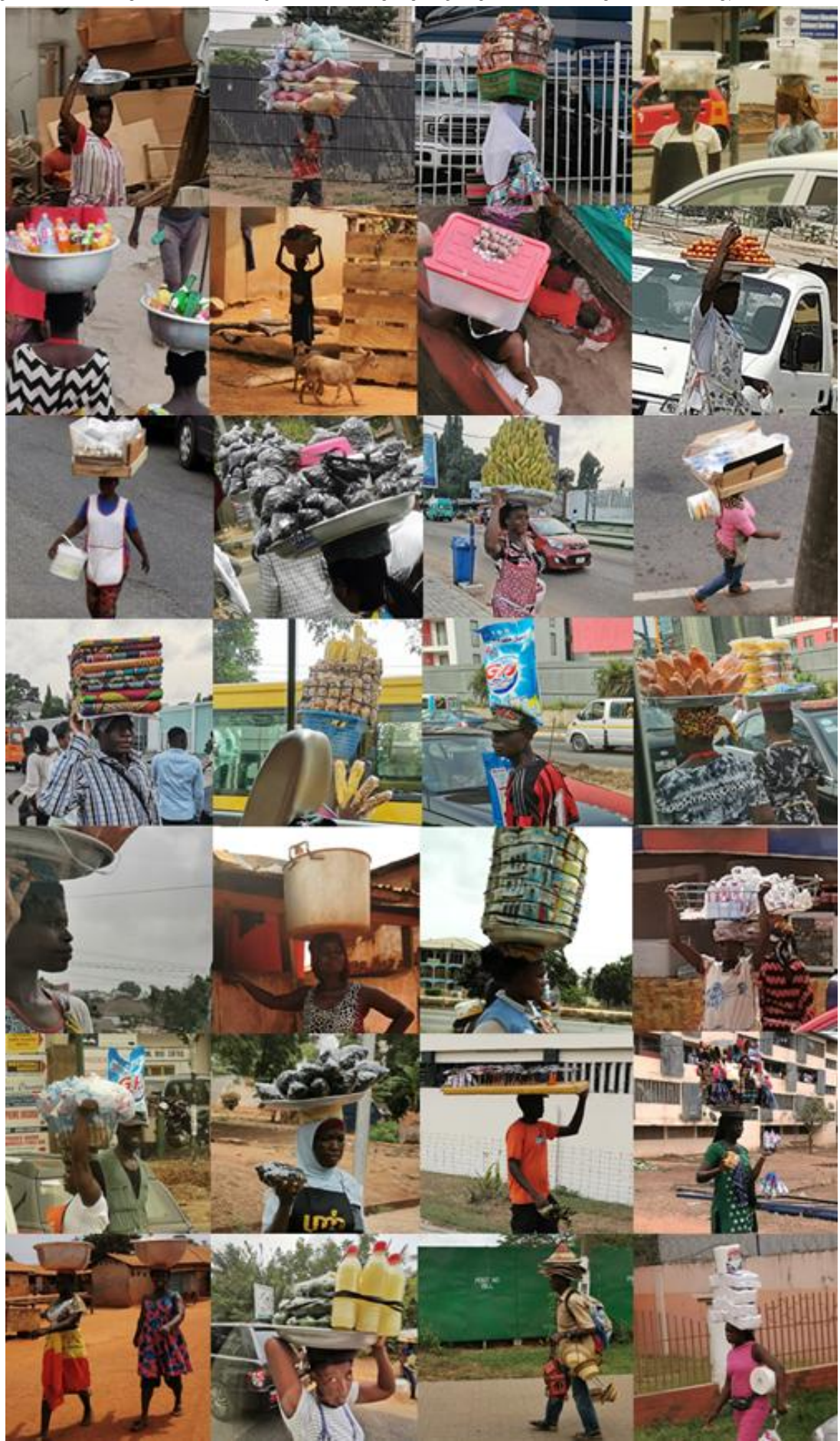


vállalás, az oktatás, a család és a házasság terén is folyamatos pozitív átalakulást figyelhetünk meg, aminek hatására egy nemileg sokkal kiegyensúlyozottabb társadalom jön létre.

Végül: a nők emancipációja téma iránt érdeklődők figyelmébe ajánljuk még Szűcs (2019) írását a török nők emancipációjával kapcsolatban. Sajátos párhuzamok találhatók a két ország között.

\section{Irodalom}

Brewer, C.; Rice-Ogletree, K., Victoria, M. és a Konko Falu harmadikosai (2014): $C$ is for Cocoa: An alphabet book about Ghana, West Africa, and the food, plants, and animals found in its environment. Indiana: Unchained Spirit Enterprises.

Briggs, Ph. és Rushton, K. (2019): Ghana (Bradt Travel Guide). Johannesburg: Bradt Travel Guides.

Huq, M. és Tribe, M. (2018): Agriculture. In: Huq, M. és Tribe, M. (eds.): The Economy of Ghana: 50 Years of Economic Development 1st ed. London: Palgrave Macmillan. pp. 83-107. doi: 10.1057/978-1-137-602435_5
Nagy Világatlasz (2008). Nyír-Karta Bt., Nyíregyháza.

Net1: Ghána. Wkikpédia. Letöltés: 2020.03. 13. Web: https://hu.wikipedia.org/wiki/ Gh\%C3\%A1na

Net2: Ghana Regions. About Ghana. Kesenews. Letöltés: 2020.03.13. Web: https://kesenews.com/regions-ghanaregions-and-capitals-ghana-regions/

Net3: 2019 World Press Freedom Index. Reporters without borders. Letöltés: 2020.03.13. Web: https://rsf.org/en/ ranking

Net4: 10 történelmi és híres börtön. Látványosságok. Letöltés: 2020.03.13. Web: https://latvanyossagok.hu/10-tortenelmies-hires-borton/

Salm, S. J. és Falola, T. (2002): Culture and Customs of Ghana (Culture and Customs of Africa). Westport: Greenwood Press.

Szűcs Lászlóné Siska K. (2019): A török nők emancipációja. Lélektan és hadviselés - interdiszciplináris folyóirat, I. évf. 2019/1. szám. 73-83. doi: 10.35404/LH.2019.1.73

Van Dantzig, A. (1999): Forts and Castles of Ghana. Accra: Sedco Publishing. 